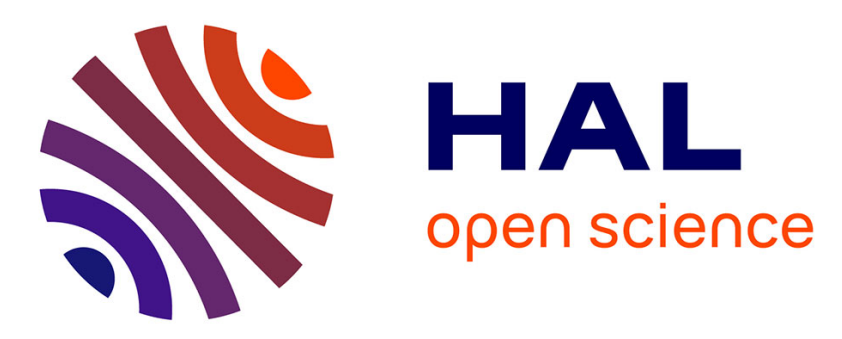

\title{
Importance of chloride homeostasis in the operation of rhythmic motor networks
}

\author{
Jean-Charles Viemari, Rémi Bos, Pascale Boulenguez, Cécile Brocard, \\ Frédéric Brocard, Hélène Bras, Patrice Coulon, Sylvie Liabeuf, Edouard \\ Pearlstein, Karina Sadlaoud, et al.
}

\section{To cite this version:}

Jean-Charles Viemari, Rémi Bos, Pascale Boulenguez, Cécile Brocard, Frédéric Brocard, et al.. Importance of chloride homeostasis in the operation of rhythmic motor networks. Breathe, Walk and Chew: The Neural Challenge: Part II, 188, Elsevier, pp.3-14, 2011, Progress in Brain Research, 10.1016/B978-0-444-53825-3.00006-1 . hal-03470150

\section{HAL Id: hal-03470150 https://hal.science/hal-03470150}

Submitted on 9 Dec 2021

HAL is a multi-disciplinary open access archive for the deposit and dissemination of scientific research documents, whether they are published or not. The documents may come from teaching and research institutions in France or abroad, or from public or private research centers.
L'archive ouverte pluridisciplinaire HAL, est destinée au dépôt et à la diffusion de documents scientifiques de niveau recherche, publiés ou non, émanant des établissements d'enseignement et de recherche français ou étrangers, des laboratoires publics ou privés. 


\title{
Importance of chloride homeostasis in the operation of rhythmic motor networks
}

\author{
Jean-Charles Viemari, Rémi Bos, Pascale Boulenguez, Cécile Brocard, \\ Frédéric Brocard, Hélène Bras, Patrice Coulon, Sylvie Liabeuf, Edouard Pearlstein, \\ Karina Sadlaoud, Aurélie Stil, Sabrina Tazerart and Laurent Vinay*
}

Laboratoire Plasticité et Physio-Pathologie de la Motricité (UMR6196), Centre National de la Recherche Scientifique (CNRS) \& Aix-Marseille Université, 31 Chemin Joseph Aiguier, Marseille Cedex 20, France

\begin{abstract}
GABA and glycine are classically called "inhibitory" amino acids, despite the fact that their action can rapidly switch from inhibition to excitation and vice versa. The postsynaptic action depends on the intracellular concentration of chloride ions $\left(\left[\mathrm{Cl}^{-}\right]_{\mathrm{i}}\right)$, which is regulated by proteins in the plasma membrane: the $\mathrm{K}^{+}-\mathrm{Cl}^{-}$cotransporter $\mathrm{KCC} 2$ and the $\mathrm{Na}^{+}-\mathrm{K}^{+}-\mathrm{Cl}^{-}$cotransporter $\mathrm{NKCC} 1$, which extrude and intrude $\mathrm{Cl}^{-}$ions, respectively. A high $\left[\mathrm{Cl}^{-}\right]_{\mathrm{i}}$ leads to a depolarizing (excitatory) action of GABA and glycine, as observed in mature dorsal root ganglion neurons and in motoneurons both early during development and in several pathological conditions, such as following spinal cord injury. Here, we review some recent data regarding chloride homeostasis in the spinal cord and its contribution to network operation involved in locomotion.
\end{abstract}

Keywords: inhibition; networks; KCC2; chloride; activity.

\section{Introduction}

Synaptic inhibition mediated by GABA and glycine strongly modulates mammalian neuronal networks from the early life to adulthood. The postsynaptic action of these neurotransmitters on $\mathrm{GABA}_{\mathrm{A}}$ and

\footnotetext{
*Corresponding author. Tel.: (+33)-4-91-16-40-86; Fax.: (+33)-4-91-77-50-84
}

glycine receptors depends on the intracellular concentration of chloride ions $\left(\left[\mathrm{Cl}^{-}\right]_{\mathrm{i}}\right)$ in the target cell. In adult healthy neurons, the activation of $\mathrm{GABA}_{\mathrm{A}}$ and glycine receptors results in an inward flux of $\mathrm{Cl}^{-}$ and membrane potential hyperpolarization. Therefore, the inhibitory action of glycine and GABA consists in both shunting incoming excitatory currents and moving the membrane potential away from the action potential threshold. This "classical" 
hyperpolarizing inhibition is not observed in immature neurons; inhibitory postsynaptic potentials (IPSPs) as well as glycine- and GABA-evoked potentials are instead depolarizing and often excitatory (Gao and Ziskind-Conhaim, 1995; Takahashi, 1984; Wu et al., 1992; Ziskind-Conhaim, 1998), because of a high $\left[\mathrm{Cl}^{-}\right]_{\mathrm{i}}$. The $\left[\mathrm{Cl}^{-}\right]_{\mathrm{i}}$ is regulated by transporters in the membrane (Delpire and Mount, 2002). Chloride homeostasis and the regulation of those transporters appear as an important emerging mechanism, by which the strength, as well as the polarity, of postsynaptic inhibition can be controlled, even in adult tissue. This review will center on these issues.

\section{Differential control of chloride homeostasis in primary afferents and motoneurons}

The transport of $\mathrm{Cl}^{-}$by cation-chloride cotransporters is driven by the concentration gradients of cations (Payne et al., 2003; Fig. 1a). The $\mathrm{Na}^{+}$gradient generated by the $\mathrm{Na}^{+} / \mathrm{K}^{+}$ATPase fuels the inward-directed $\mathrm{Cl}^{-}$pump $\mathrm{Na}^{+}-\mathrm{K}^{+}-\mathrm{Cl}^{-}$cotransporter, $\mathrm{NKCC} 1$, which is important in active accumulation of intracellular $\mathrm{Cl}^{-}$in immature neurons in several brain areas (Dzhala et al., 2005; Ikeda et al., 2003; Plotkin et al., 1997; Sun and Murali, 1999; Vardi et al., 2000). It is down-regulated with development except in a few neurons such as dorsal root ganglion (DRG) neurons (Sung et al., 2000). As shown in Fig. 1b, the transporter is predominantly located at the plasma membrane of these cells. By contrast, DRG neurons from a NKCC1 knockout animal demonstrate the complete absence of NKCC1 expression (Fig. 1c). Gramicidin perforated-patch recordings from DRG neurons isolated from these mice reveal that $E_{\mathrm{GABA}}$ is consistently more depolarized in DRG neurons from wild type compared with neurons from NKCC1 knock-out mice ( -37 and $-53 \mathrm{mV}$, respectively; Fig. 1d). This corresponds to intracellular $\mathrm{Cl}^{-}$concentrations of 46 and $24 \mathrm{mM}$, respectively (Sung et al., 2000).
Inhibitory amino acid transmission to motoneurons undergoes marked changes during development. There is a developmental switch from predominantly long-duration GABAergic to short-duration glycinergic currents (Gao et al., 2001) and an increase in the density of the glycine currents (Gao and Ziskind-Conhaim, 1995). These physiological observations are correlated with a developmental down-regulation of $\mathrm{GABA}_{\mathrm{A}}$ receptors and a concomitant up-regulation of glycine receptors (Sadlaoud et al., 2010). A striking observation is related to chloride homeostasis. Glycine- and GABA-evoked potentials are depolarizing and often excitatory (Gao and Ziskind-Conhaim, 1995; Takahashi, 1984; Wu et al., 1992; Ziskind-Conhaim, 1998) early during development, because of a high $\left[\mathrm{Cl}^{-}\right]_{\mathrm{i}}$ that favors $\mathrm{Cl}^{-}$efflux through $\mathrm{GABA}_{\mathrm{A}^{-}}$or glycineoperated $\mathrm{Cl}^{-}$channels. For instance, a brief application of glycine onto the in vitro spinal cord isolated from fetal rats, at embryonic day (E) 15.5 (i.e., one week prior to birth), evokes excitatory responses that are abolished by strychnine (Nishimaru et al., 1996). The cation-chloride cotransporter NKCC1 (Delpy et al., 2008) and the anion exchanger AE3 (Gonzalez-Islas et al., 2009) play a significant role in accumulating chloride in immature motoneurons. With development, $\left[\mathrm{Cl}^{-}\right]_{\mathrm{i}}$ decreases, leading to a shift of the chloride equilibrium potential toward further negative values, and thereby to a change in glycine and GABA-evoked potentials from depolarization to hyperpolarization (Gao and Ziskind-Conhaim, 1995; Jean-Xavier et al., 2006; Stil et al., 2009; Takahashi, 1984; Vinay and Jean-Xavier, 2008). The up-regulation of the outward-directed $\mathrm{Cl}^{-}$ pump, the neuron specific $\mathrm{K}^{+}-\mathrm{Cl}^{-}$cotransporter $\mathrm{KCC} 2$, is widely accepted to underlie the shift from GABA/glycine-induced depolarization to hyperpolarization in several regions of the central nervous system (Delpire and Mount, 2002; Payne et al., 2003; Rivera et al., 1999, 2004). In contrast to DRG neurons, mature motoneurons highly express this transporter (Fig. 1e; Boulenguez et al., 2010; Delpy et al., 2008; Hübner et al., 2001; Jean- 

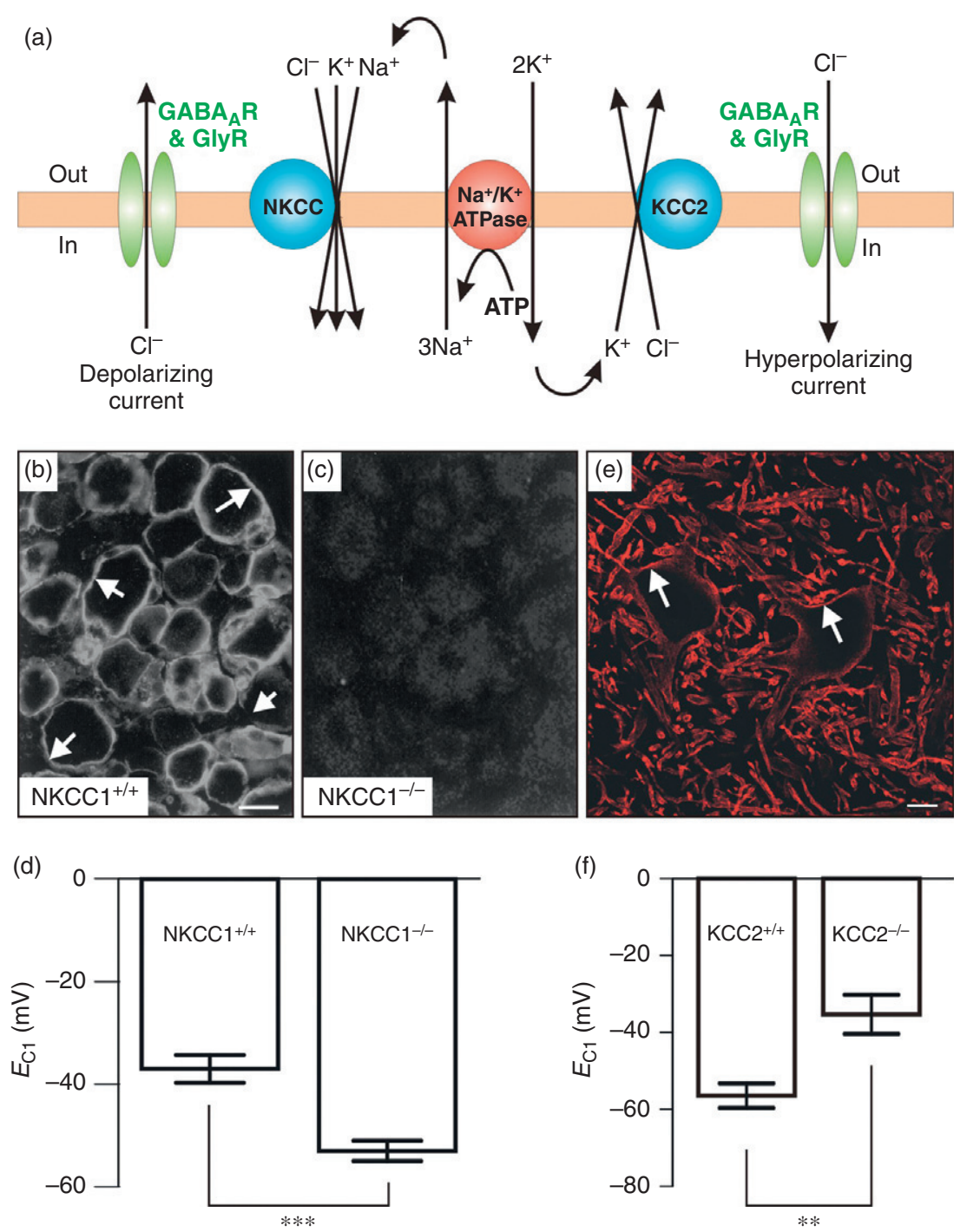

Fig. 1. Different mechanisms underlie chloride homeostasis in dorsal root ganglion (DRG) neurons and motoneurons. (a) Schematic illustration (adapted from Payne et al., 2003) of the contribution of cation-chloride cotransporters to the regulation of $\left[\mathrm{Cl}^{-}\right]_{\mathrm{i}}$. $\mathrm{Under}^{-}$ physiological conditions, NKCC1 and KCC2 cotransporters intrude and extrude $\mathrm{Cl}^{-}$, respectively. Arrows indicate the direction of net transports, which are driven by the concentration gradients of cations, generated by the $\mathrm{Na}^{+} / \mathrm{K}^{+}-\mathrm{ATPase}$. As a result of NKCC1 activity in DRG neurons, activation of $\mathrm{GABA}_{\mathrm{A}}$ receptors generates a depolarizing current whereas the activity of KCC2 cotransporters in adult motoneurons underlies hyperpolarizing currents across anion-permeable channels. (b-d) Adapted from Sung et al. (2000). Control mouse DRG neurons highly express the NKCC1 protein (b). The signal is predominantly located at the cell membrane (arrows). Note the presence of a few neurons with a minimal amount of cotransporter expression (arrowhead). Immunofluorescence staining shows the absence of NKCC1 expression in DRG neurons from homozygote mutant mice (c). Scale bar, $20 \mu \mathrm{m}$. As a result of the lack of NKCC1, $E_{\mathrm{Cl}}$ is significantly more negative in NKCC1 knock-out mice, compared to controls (d). (e) Strong KCC2 expression in ventral horn of adult rats. Note the labeling of the plasma membrane (arrows) of motoneurons. (f) Application of a $\mathrm{GABA}_{\mathrm{A}^{-}}$and glycine-receptor agonists in the recording chamber induce a larger depolarization in lumbar motoneurons in KCC2 knock-out mice than in wild-type animals (Adpated from Hübner et al., 2001). 
Xavier et al., 2006; Stein et al., 2004; Stil et al., 2009; Vinay and Jean-Xavier, 2008). Motoneurons are significantly more depolarized $(>30 \mathrm{mV})$ by GABA or glycine in KCC2 knock-out mice at E18 than in wild type $(\sim 10 \mathrm{mV}$; Fig. $1 \mathrm{f}$; Hübner et al., 2001). Altogether, these data demonstrate that NKCC1 and KCC2 cotransporters are important for maintaining high and low chloride concentrations in mature DRG neurons and motoneurons, respectively.

\section{Contribution of chloride homeostasis to cell excitability}

According to the classical view, postsynaptic inhibition induced by the activation of $\mathrm{GABA}_{\mathrm{A}}$ and glycine receptors consists in two mechanisms: shunting incoming excitatory currents and moving the membrane potential away from the action potential threshold. As already mentioned, this hyperpolarization from rest is not observed in immature spinal neurons (Gao and ZiskindConhaim, 1995; Takahashi, 1984; Wu et al., 1992; Ziskind-Conhaim, 1998), thereby raising the question of the effect of subthreshold depolarizing IPSPs on neuronal excitability. It is widely accepted that despite their depolarizing action, these potentials are inhibitory in immature spinal motoneurons because of the shunting mechanism. On the basis of two reports on the cortex (Gulledge and Stuart, 2003) and the hypothalamus (Gao et al., 1998), we challenged the idea that depolarizing IPSPs may interact with excitatory inputs and increase the excitability of motoneurons (Jean-Xavier et al., 2007). We demonstrated that depolarizing IPSPs have an excitatory action by facilitating action potential generation when paired with subthreshold excitatory inputs (Fig. 2a). The effect of depolarizing IPSPs on excitability therefore depends on the relative weights of the inhibitory action of the shunting mechanisms and the excitatory action of the depolarization. The value of $E_{\mathrm{Cl}}$ affects the strength of inhibitory connections within spinal cord locomotor networks; the more positive $E_{\mathrm{Cl}}$, the lower the efficacy of inhibition. A first key point is the timing between inhibitory and excitatory inputs. The inhibitory action of shunting is exerted over a rather short period after IPSP onset (Fig. 2a, blockade of action potentials evoked by current pulses). In contrast, the time course of the depolarization is much longer, because of the time constant of the membrane, such that the excitations occurring in the late phase of the depolarizing IPSP sum up with the depolarization whereas the conductance has returned to baseline (Fig. 2a; bottom trace showing a subthreshold current pulse triggering an action potential when occurring in the decay phase of the IPSP). A second key point, revealed by the use of a model (Fig. 2b), is the distance between inhibitory and excitatory synapses. The inhibitory action of conductance changes is local whereas the depolarization spreads electrotonically along the dendrites. Consequently, GABA/glycine synapses exert a strong inhibition on proximal excitatory inputs (Fig. 2c; somatic excitations and inhibitory synapses on the soma and on proximal dendrites) and a pure facilitation (whatever the timing) on distal excitation (Fig. 2c, bottom graph with inhibitory inputs $200 \mu \mathrm{m}$ away from excitatory synapses).

\section{Contribution of chloride dynamics to network activity}

Maturation of chloride homeostasis affects network activity. There is a switch in the contribution of chloride-mediated conductances to spontaneous activity from excitation to inhibition during late gestation. A rhythmic spontaneous activity can be recorded in vitro very early ( $\sim$ E12-E14 in rodents), when many lumbar motoneurons are still migrating and extending their peripheral projections (Hanson and Landmesser, 2003). Electrical transmission plays a significant role in the generation of episodes since blockade of gap junction coupling by carbenoxolone abolishes 
(a)

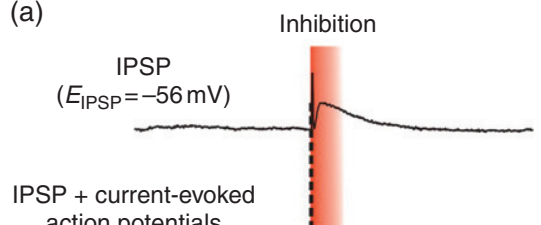

action potentials

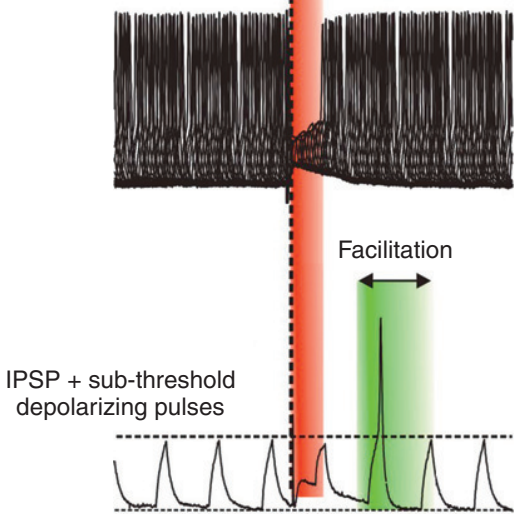

$20 \mathrm{mV}$
$100 \mathrm{~ms}$ (b)

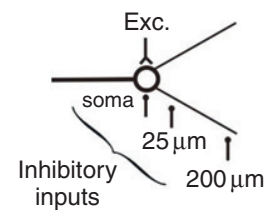

(c)
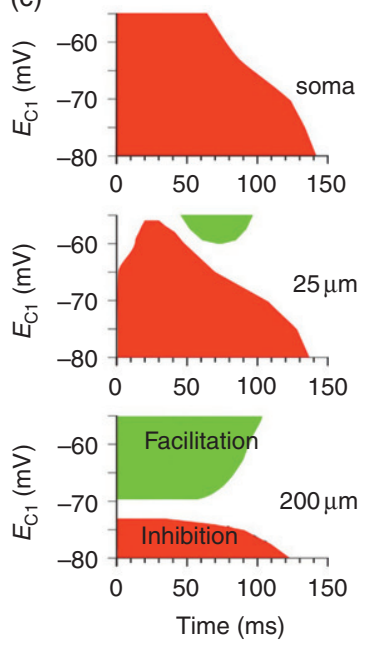

Fig. 2. Inhibitory and excitatory actions of depolarizing inhibitory postsynaptic potentials (IPSPs). (a) Depolarizing IPSP evoked in a lumbar motoneuron $\left(V_{\mathrm{REST}}:-68 \mathrm{mV}\right)$ by electrical stimulation of the ventral funiculus of the spinal cord isolated from neonatal rat (top trace). Recordings were performed after blocking excitatory amino acid transmission. Suprathreshold current pulses were injected to test the ability of the inhibitory input to block action potentials (middle trace: 50 sweeps). (b) Model used in the simulations to test the interaction between depolarizing IPSPs and subthreshold excitatory inputs set on the soma. (c) Global pictures of inhibitory (inhibition of suprathreshold EPSPs) and excitatory (facilitation of subthreshold EPSPs) effects depending on both $E_{\mathrm{Cl}}$ and the location of inhibitory inputs. Note that IPSPs generated on the soma, close to the excitations are inhibitory, whatever the value of $E_{\mathrm{Cl}}$, because of shunting mechanisms. For inhibitory inputs on proximal segments of dendrites $(25 \mu \mathrm{m})$, the timing is important when $E_{\mathrm{Cl}}$ is set at depolarized values $(>-60 \mathrm{mV})$; the initial part of the IPSP is inhibitory whereas the late phase can facilitate subthreshold excitations. The action of distal inhibitory inputs $(200 \mu \mathrm{m})$ can switch from inhibition to excitation within a narrow range of $E_{\mathrm{Cl}}$ values, close to the resting membrane potential. (a-c) Adapted from Jean-Xavier et al. (2007).

the rhythmic episodes. The relative contribution and the role of the different neurotransmitters change prior to birth (Hanson and Landmesser, 2003; Myers et al., 2005; Ren and Greer, 2003). At the earliest stages, the spinal networks comprising cholinergic and glycinergic synaptic interconnections are capable of generating rhythmic activity, while GABAergic synapses play a role in supporting this activity. Stimulation of motor neurons at this stage elicits episodes of activity that propagate through the lumbar spinal cord suggesting that motoneurons make excitatory connections on each other and on glycine/ GABAergic interneurons via nicotinic receptors. At a later stage (E16.5-E17.5), the spontaneous activity results from the combined action of nonNMDA (glutamatergic), nicotinic (acetylcholine), glycine, and $\mathrm{GABA}_{\mathrm{A}}$ receptors. Closer to birth (E18.5-E21.5), glutamate drive acting via nonNMDA receptors is primarily responsible for the rhythmic activity. Application of strychnine to block glycine receptors markedly reduces and increases the bursting frequency in early and late embryos, respectively, suggesting that glycine 
switches from an excitatory to an inhibitory contribution to spontaneous activity. This transition occurs at about the same time as the switch from cholinergic to glutamatergic transmission.

The fact that the classical inhibitory neurotransmitters can be functionally excitatory moves the balance between excitatory and inhibitory drives toward excitation. This renders developing networks hyperexcitable. Intracellular chloride concentration undergoes significant changes during spontaneous activity in the chick spinal cord (Chub and O'Donovan, 2001). After an episode, the chloride equilibrium potential falls by $\sim 10 \mathrm{mV}$, corresponding to a decline of intracellular chloride of $\sim 15 \mathrm{mM}$. This reduces the excitatory contribution of GABA and glycine and hence network excitability. The intracellular chloride concentration is restored during the interepisode interval, as a result presumably of inward chloride pumping via cation-chloride cotransporters, leading to a progressive increase in network excitability. The importance of chloride dynamics in the genesis of spontaneous activity in the in vitro chick spinal cord between E9 and E11 was confirmed by the use of a model (Marchetti et al., 2005).

Application of serotonin on the spinal cord at birth, to activate the CPGs, evokes a fictive locomotor pattern consisting of alternation between the motor bursts on the left and right sides of the spinal cord, as well as alternation between flexor and extensor bursts on the same side. The same kind of experiments made five days prior to birth reveals a motor pattern with all bursts in phase (Iizuka et al., 1997; Nishimaru and Kudo, 2000). The left-right alternation appears two days later but rhythmic bursts still occur synchronously in flexors and extensors. The transition from synchrony to alternation in the left and right ventral roots is likely due to the maturation of chloride homeostasis.

In the respiratory network, although GABA/ glycine-mediated inhibition is not essential for rhythm generation in neonatal rodent, it is well known that synaptic inhibition is important for setting the different phases of the respiratory rhythm and regulates both the excitability of glutamatergic connections and the intrinsic membrane properties (Busselberg et al., 2001a,b; Ramirez et al., 1997; Shao and Feldman, 1997). As described in the case of spinal cord, the $\left[\mathrm{Cl}^{-}\right]_{\mathrm{i}}$ determines the functional role of inhibitory neurotransmitters. The transition from an excitatory to an inhibitory effect occurs earlier on inspiratory neurons than in the lumbar spinal cord ( $\sim$ E19; Ren and Greer, 2006). From this time onward, GABA and glycine hyperpolarize inspiratory neurons and suppress respiratory frequency.

It is important to note that $\mathrm{KCC} 2$ cotransporters are sensitive to subtle changes in the extracellular concentration of potassium ions $\left(\left[\mathrm{K}^{+}\right]_{\mathrm{o}}\right)$. A raise of $\left[\mathrm{K}^{+}\right]_{\mathrm{o}}$ from $2-3$ to $9-10 \mathrm{mM}$ is sufficient to reverse the driving force for the net $\mathrm{K}-\mathrm{Cl}$ cotransport, thus allowing $\mathrm{KCC} 2$ to operate in a reverse mode as a net influx pathway (Payne et al., 2003). As a consequence, such a raise induces a 10 - to $20-\mathrm{mV}$ depolarizing shift of $E_{\mathrm{Cl}}$ (Ren and Greer, 2006; Vinay and JeanXavier, 2008) in medullary slices and lumbar spinal cord preparations, respectively). Raising $\left[\mathrm{K}^{+}\right]_{\mathrm{o}}$ is commonly used as a methodological tool to increase the excitability of in vitro preparations. This may, in addition, modify the strength of postsynaptic inhibition within networks and explain some inconsistency among results obtained in different experimental conditions.

The effects of GABA on the respiratory network highly depend on the expression and the functionality of cation-chloride cotransporters. During the early life, $\mathrm{NKCC} 1$ is expressed at high levels and perturbations of its functionality by removing $\left[\mathrm{Na}^{+}\right]_{\mathrm{o}}$ or by application of bumetanide shifts $E_{\mathrm{Cl}}$ to a more hyperpolarized value and reverses the excitatory effect of $\mathrm{GABA}_{\mathrm{A}}$ receptor agonists (muscimol), whereas blockade of KCC2 by furosemide has no effect (Ren and Greer, 2006). In contrast, in neonatal preparations, furosemide depolarizes $E_{\mathrm{Cl}}$ and blocks the inhibitory effect of muscimol on respiratory frequency. At that time, 
blockade of NKCC1 has no significant effect. These results are consistent with a developmental increase of $\mathrm{KCC} 2$ expression in the respiratory network, as in the locomotor system.

\section{Primary afferent depolarizations and antidromic discharges as part of the motor network}

It is well established that one form of presynaptic inhibition in the vertebrate spinal cord is associated with primary afferent depolarization (PAD, Alvarez-Leefmans et al., 1998; Rudomin, 1990; Rudomin et al., 1993) and that GABA, through the activation of $\mathrm{GABA}_{\mathrm{A}}$ receptors, plays a major role in the generation of PAD. Axo-axonic interactions between GABAergic terminals and primary afferents have been demonstrated (see Alvarez, 1998, for review). PADs are reduced by $\mathrm{GABA}_{\mathrm{A}}$ receptor antagonists (Curtis and Lodge, 1982; Eccles et al., 1963; Levy, 1975; Rudomin et al., 1981). When PADs are large enough to reach firing threshold, they trigger discharges that are antidromically conducted into peripheral nerves. This was first demonstrated by recording the reflex response elicited in dorsal roots, by electrical stimulation of an adjacent dorsal root ("dorsal root reflex," Barron and Matthews, 1938; Toennies, 1938, see Kerkut and Bagust, 1995, for review). Antidromic discharges of primary afferents have been observed during locomotion in the cat (fictive locomotion: Beloozerova and Rossignol, 1999; Dubuc et al., 1988; Duenas et al., 1990; Gossard et al., 1991; treadmill locomotion: Beloozerova and Rossignol, 2004; Dubuc et al., 1985; Rossignol et al., 1998) and in the rat (Pilyavskii et al., 1988). A spontaneous antidromic activity in the dorsal roots has been described in the in vitro spinal cord isolated from adult (Bagust et al., 1989; Chen et al., 1993) or young hamsters (Abdul-Razzak et al., 1994; see Kerkut and Bagust, 1995, for review). Antidromic discharges are also recorded from lumbar dorsal roots in the neonatal rat spinal cord in vitro (Fellippa-Marques et al., 2000; Kremer and Lev-Tov, 1998; Vinay and Clarac, 1999; Vinay et al., 1999). Most of these action potentials are blocked by bath application of bicuculline or picrotoxin, two $\mathrm{GABA}_{\mathrm{A}}$ receptor antagonists. Some activity occurs spontaneously, consisting of rhythmic bursts, and is therefore likely triggered by a centrally generated rhythm. A motor activity is sometimes recorded from ventral roots, occurring in phase with the dorsal root burst (Fig. 3a). Intracellular recordings from motoneurons show subthreshold depolarizations, confirming the existence of neuronal connections that coactivate the motoneurons and the primary afferent terminals. Alternatively, antidromic discharges in dorsal roots may have postsynaptic effects in lumbar motoneurons and first-order interneurons, as shown in the trigeminal system.

Lund and coworkers indeed demonstrated the existence of such antidromic discharges during fictive mastication (Kolta et al., 1995; Verdier et al., 2003). They proposed the very elegant hypothesis of a functional compartmentalization of muscle spindle afferents (Fig. 3b). In contrast to other primary afferents, the cell bodies of primary afferents that innervate the spindles of jaw-closing muscles are located in the trigeminal mesencephalic nucleus (Nvmes) and not in DRG. During fictive mastication, the firing patterns recorded from the soma differ markedly from those recorded from the caudal compartment of the central axon of these afferents. In $65 \%$ of cells, activation of the motor circuits during fictive mastication does not alter tonic orthodromic activity induced by stretch of the jaw-closing muscles and in one-third of cases only, a phasic inhibition of this activity is observed, coincident with jaw-opening phase of the cycle. In contrast, phasic inhibition is seen in the great majority $(83 \%)$ of recordings from the caudal compartment of the central axon. In addition, these inhibitions alternate with phasic excitation occurring in the jaw-closing phase. The 

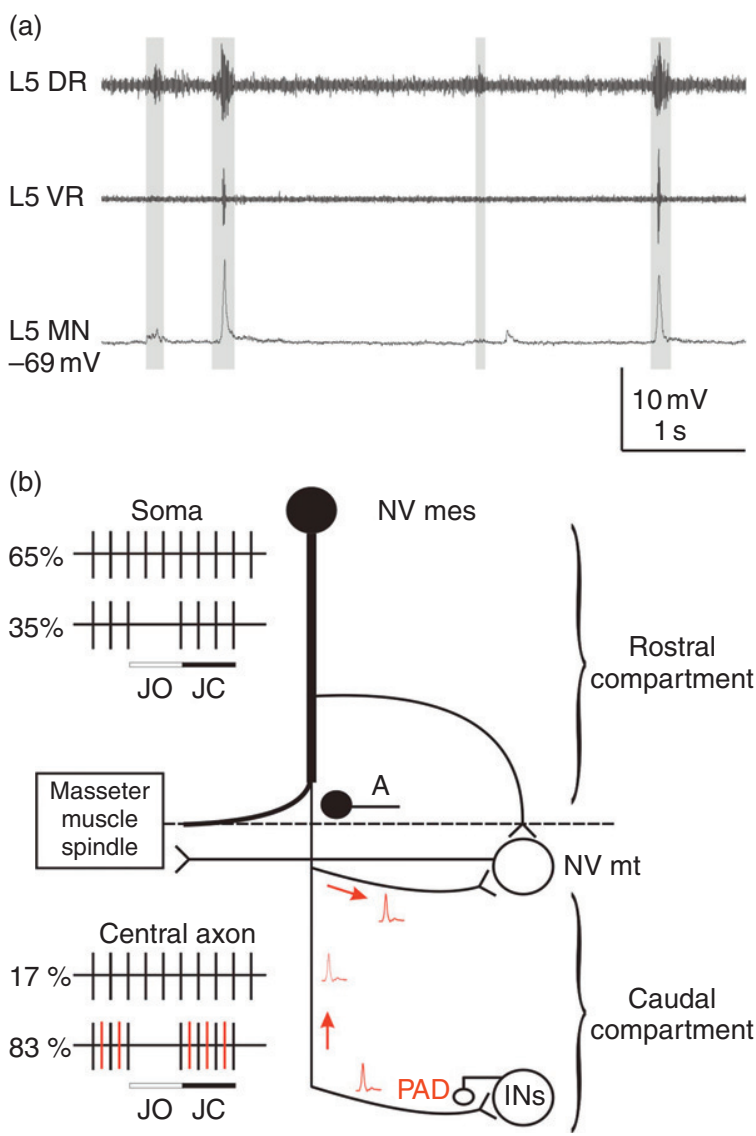

Fig. 3. Antidromically propagated discharges triggered by primary afferent depolarizations. (a) Spontaneous bursting activity recorded from lumbar dorsal and ventral roots in the in vitro spinal cord preparation isolated from neonatal rats. (b) Functional compartmentalization of jaw-closing muscle spindle afferents, redrawn from Verdier et al. (2003). The cell bodies of the afferents are located in the trigeminal mesencephalic nucleus (NV mes) and have a long descending axon that gives off branches at many levels. Axonal branches terminate on jaw-closing motoneurons in the trigeminal motor nucleus (NV mt) and on interneurons (INs). During fictive mastication, stretch-induced tonic activity is unaltered in $65 \%$ of somatic recordings and is phasically inhibited during the jaw-opening (JO) phase in $35 \%$ of cases. In contrast, phasic inhibition during the JO phase alternates with a phasic excitation during the jaw-closing (JC) phase in the majority of recordings from caudal axons. Antidromic action potentials generated by PAD (in red) of the central terminals do not reach the soma but do reach trigeminal motoneurons and interneurons via collaterals. (a) represents hypothetical synapses on the axon that stops antidromic potentials from reaching the cell body. (For interpretation of the references to color in this figure legend, the reader is referred to the Web version of this chapter.)

extraspikes appearing in the latter phase have been attributed to antidromic action potentials generated by PAD of the central terminals. These spikes do not reach the soma but do reach trigeminal motoneurons via collaterals. They provide additional excitation to trigeminal MNs. To summarize, the central axon plays the role of a premotor interneuron carrying signals from the CPG via a set of presynaptic terminals to motoneurons whereas the rostral portion of the neuron provides feedback from its receptors, although even this sensory feedback is phasically gated by the CPG. The possibility that a similar mechanism also applies to the spinal cord is under investigation.

\section{Dysfunction of chloride homeostasis in pathological conditions}

The hyperpolarizing shift of $E_{\mathrm{Cl}}$ from above to below the resting membrane potential in rodent motoneurons occurs during perinatal development, a time window during which pathways descending from the brainstem arrive in the lumbar enlargement (Brocard et al., 1999; Vinay et al., 2000, 2002). A complete spinal cord transection was performed on the day of birth to investigate the contribution of descending pathways to the maturation of chloride homeostasis (Jean-Xavier et al., 2006). This early removal of supraspinal influences prevented both the hyperpolarizing shift of $E_{\mathrm{Cl}}$ and the up-regulation of $\mathrm{KCC} 2$ that normally occur during the first postnatal week. These results may account for the disorganization of the locomotor pattern that is observed in these animals following neonatal spinal cord transaction (Norreel et al., 2003). 
It is well known that several inhibitory reflex mechanisms are decreased in patients after SCI (Boorman et al., 1996; Mazzocchio and Rossi, 1997; Morita et al., 2001). The mechanisms responsible for this reduced inhibition were unknown until recently. Based on the above-mentioned results showing that descending pathways modulate chloride homeostasis, we hypothesized that a spinal cord injury in adults may affect the expression of KCC2 in the lumbar spinal cord and hence the strength of postsynaptic inhibition. We showed that the expression of $\mathrm{KCC} 2$ in the plasma membrane of motoneurons is reduced after spinal cord injury (Boulenguez et al., 2010). We demonstrated that a blockade of these cotransporters in intact animals reproduces some of the observations made in spastic paraplegic rats, suggesting that a down-regulation of KCC2 can contribute to the hyperexcitability of spinal networks, which is the hallmark of spasticity following spinal cord injury (Boulenguez et al., 2010).

\section{Conclusion}

To conclude, primary afferent terminal and motoneurons exhibit opposite mechanisms for chloride homeostasis. A high $\left[\mathrm{Cl}^{-}\right]_{\mathrm{i}}$ maintained by NKCC1 cotransporters is responsible for PADs. The action potentials that are generated by PADs reaching firing threshold have long been considered as an epiphenomenon or an artifact due to the experimental conditions. The ubiquity of their observation in different motor networks underscores the need to investigate their role further. A low $\left[\mathrm{Cl}^{-}\right]_{\mathrm{i}}$ is maintained in healthy motoneurons by $\mathrm{KCC} 2$ cotransporters; this is a requirement for a strong postsynaptic inhibition. The excitatory effects of GABA and glycine used to be considered only in a developmental perspective. The demonstration that KCC2 transporters and chloride homeostasis are affected in pathological conditions sheds new light on these mechanisms. Restoring chloride homeostasis, by up-regulating the functionality of KCC2 transporters, may pave the way for new treatments aimed at reducing spasticity following spinal cord injury. The demonstration that depolarizing IPSPs can facilitate subthreshold excitations also warrants further studies to investigate how these interactions contribute to synaptic integration and plasticity. That $\left[\mathrm{K}^{+}\right]_{\mathrm{o}}$ and $E_{\mathrm{Cl}}$ are critically dependent upon the activity raises the possibility that the role of GABA/glycinergic inputs may reversibly switch from inhibition to excitation, depending on the recent experience of the network.

\section{Acknowledgments}

Our study on the plasticity of inhibitory synaptic transmission in the spinal cord is supported by grants (to L.V.) from the French Agence Nationale pour la Recherche, the French Institut pour la Recherche sur la Moelle épinière et l'Encéphale (to L.V.) and the Christopher and Dana Reeve Foundation (VB1-0502-2 and VB2-08012). K.S. received a grant from the Association Française contre les Myopathies (Grant 13912). S.T. received a grant from the Fondation pour la Recherche Médicale (Grant FDT20081213783).

\section{References}

Abdul-Razzak, R., Bagust, J., \& Kerkut, G. A. (1994). Postnatal changes in the dorsal root reflex in the isolated spinal cord of the hamster Mesocricetus auratus. Comparative Biochemistry and Physiology, 107C, 195-204.

Alvarez, F. J. (1998). Anatomical basis for presynaptic inhibition of primary sensory fibers. In P. Rudomin, L. M. Romo \& S. Mendell (Eds.), Presynaptic inhibition and neural control (pp. 13-49). Oxford: Oxford University Press.

Alvarez-Leefmans, F. J., Nani, A., \& Marquez, S. (1998). Chloride transport, osmotic balance, and presynaptic inhibition. In P. Rudomin, R. Romo \& L. M. Mendell (Eds.), Presynaptic inhibition and neural control (pp. 50-79). Oxford: Oxford University Press.

Bagust, J., Kerkut, G. A., \& Rakkah, N. I. A. (1989). The dorsal root reflex in isolated mammalian spinal cord. Comparative Biochemistry and Physiology, 93A, 151-160. 
Barron, D. H., \& Matthews, B. H. C. (1938). Dorsal root reflexes. Journal of Physiology (London), 94, 26P-27P.

Beloozerova, I., \& Rossignol, S. (1999). Antidromic discharges in dorsal roots of decerebrate cats. I: Studies at rest and during fictive locomotion. Brain Research, 846, 87-105.

Beloozerova, I. N., \& Rossignol, S. (2004). Antidromic discharges in dorsal roots of decerebrate cats. II: Studies during treadmill locomotion. Brain Research, 996, 227-236.

Boorman, G. I., Lee, R. G., Becker, W. J., \& Windhorst, U. R. (1996). Impaired "natural reciprocal inhibition" in patients with spasticity due to incomplete spinal cord injury. Electroencephalography and Clinical Neurophysiology, 101, 84-92.

Boulenguez, P., Liabeuf, S., Bos, R., Bras, H., Jean-Xavier, C., Brocard, C., et al. (2010). Down-regulation of the potassium-chloride cotransporter $\mathrm{KCC} 2$ contributes to spasticity after spinal cord injury. Nature Medicine, 16, 302-307.

Brocard, F., Vinay, L., \& Clarac, F. (1999). Gradual development of the ventral funiculus input to lumbar motoneurons in the neonatal rat. Neuroscience, 90, 1543-1554.

Busselberg, D., Bischoff, A. M., Becker, K., Becker, C. M., \& Richter, D. W. (2001). The respiratory rhythm in mutant oscillator mice. Neuroscience Letters, 316, 99-102.

Busselberg, D., Bischoff, A. M., Paton, J. F., \& Richter, D. W. (2001). Reorganisation of respiratory network activity after loss of glycinergic inhibition. Pflügers Archiv, 441, 444-449.

Chen, Y., Bagust, J., Kerkut, G. A., \& Tyler, A. W. (1993). Correlation between spontaneous bursts of activity recorded from the dorsal roots in an isolated hamster spinal cord. Experimental Physiology, 78, 811-824.

Chub, N., \& O'Donovan, M. J. (2001). Post-episode depression of GABAergic transmission in spinal neurons of the chick embryo. Journal of Neurophysiology, 85, 2166-2176.

Curtis, D. R., \& Lodge, D. (1982). The depolarization of feline ventral horn group Ia spinal afferent terminations by GABA. Experimental Brain Research, 46, 215-233.

Delpire, E., \& Mount, D. B. (2002). Human and murine phenotypes associated with defects in cation-chloride cotransport. Annual Review of Physiology, 64, 803-843.

Delpy, A., Allain, A. E., Meyrand, P., \& Branchereau, P. (2008). NKCC1 cotransporter inactivation underlies embryonic development of chloride-mediated inhibition in mouse spinal motoneuron. Journal of Physiology, 586, 1059-1075.

Dubuc, R., Cabelguen, J. M., \& Rossignol, S. (1985). Rhythmic antidromic discharges of single primary afferents recorded in cut dorsal root filaments during locomotion in the cat. Brain Research, 359, 375-378.

Dubuc, R., Cabelguen, J.-M., \& Rossignol, S. (1988). Rhythmic fluctuations of dorsal root potentials and antidromic discharges of primary afferents during fictive locomotion in the cat. Journal of Neurophysiology, 60, 2014-2036.
Duenas, S. H., Loeb, G. E., \& Marks, W. B. (1990). Monosynaptic and dorsal root reflexes during locomotion in normal and thalamic cats. Journal of Neurophysiology, 63, 1467-1476.

Dzhala, V. I., Talos, D. M., Sdrulla, D. A., Brumback, A. C., Mathews, G. C., Benke, T. A., et al. (2005). NKCC1 transporter facilitates seizures in the developing brain. Nature Medicine, 11, 1205-1213.

Eccles, J. C., Schmidt, R. F., \& Willis, W. D. (1963). Pharmacological studies on presynaptic inhibition. Journal of Physiology (London), 168, 500-530.

Fellippa-Marques, S., Vinay, L., \& Clarac, F. (2000). Spontaneous and locomotor-related GABAergic input onto primary afferents in the neonatal rat. European Journal of Neuroscience, 12, 155-164.

Gao, X. B., Chen, G., \& van den Pol, A. N. (1998). GABAdependent firing of glutamate-evoked action potentials at AMPA/kainate receptors in developing hypothalamic neurons. Journal of Neurophysiology, 79, 716-726.

Gao, B. X., Stricker, C., \& Ziskind-Conhaim, L. (2001). Transition from GABAergic to glycinergic synaptic transmission in newly formed spinal networks. Journal of Neurophysiology, 86, 492-502.

Gao, B.-X., \& Ziskind-Conhaim, L. (1995). Development of glycine- and GABA-gated currents in rat spinal motoneurons. Journal of Neurophysiology, 74, 113-121.

Gonzalez-Islas, C. E., Chub, N. L., \& Wenner, P. (2009). NKCC1 and AE3 appear to accumulate chloride in embryonic motoneurons. Journal of Neurophysiology, 101, 507-518.

Gossard, J. P., Cabelguen, J.-M., \& Rossignol, S. (1991). An intracellular study of muscle primary afferents during fictive locomotion in the cat. Journal of Neurophysiology, 65, 914-926.

Gulledge, A. T., \& Stuart, G. J. (2003). Excitatory actions of GABA in the cortex. Neuron, 37, 299-309.

Hanson, M. G., \& Landmesser, L. T. (2003). Characterization of the circuits that generate spontaneous episodes of activity in the early embryonic mouse spinal cord. Journal of Neuroscience, 23, 587-600.

Hübner, C. A., Stein, V., Hermans-Borgmeyer, I., Meyer, T., Ballanyi, K., \& Jentsch, T. J. (2001). Disruption of KCC2 reveals an essential role of $\mathrm{K}-\mathrm{Cl}$ cotransport already in early synaptic inhibition. Neuron, 30, 515-524.

Iizuka, M., Kiehn, O., \& Kudo, N. (1997). Development in neonatal rats of the sensory resetting of the locomotor rhythm induced by NMDA and 5-HT. Experimental Brain Research, 114, 193-204.

Ikeda, M., Toyoda, H., Yamada, J., Okabe, A., Sato, K., Hotta, Y., et al. (2003). Differential development of cation-chloride cotransporters and $\mathrm{Cl}^{-}$homeostasis contributes to differential GABAergic actions between developing rat visual cortex and dorsal lateral geniculate nucleus. Brain Research, 984, 149-159. 
Jean-Xavier, C., Mentis, G. Z., O'Donovan, M., Cattaert, D., \& Vinay, L. (2007). Dual personality of GABA/glycinemediated depolarizations in the immature spinal cord. Proceedings of the National Academy of Sciences of the United States of America, 104, 11477-11482.

Jean-Xavier, C., Pflieger, J.-F., Liabeuf, S., \& Vinay, L. (2006). Inhibitory post-synaptic potentials in lumbar motoneurons remain depolarizing after neonatal spinal cord transection in the rat. Journal of Neurophysiology, 96, 2274-2281.

Kerkut, G. A., \& Bagust, J. (1995). The isolated mammalian spinal cord. Progress in Neurobiology, 46, 1-48.

Kolta, A., Lund, J. P., Westberg, K. G., \& Clavelou, P. (1995). Do muscle-spindle afferents act as interneurons during mastication? (letter; comment). Trends in Neurosciences, $18,441$.

Kremer, E., \& Lev-Tov, A. (1998). GABA-Receptor-independent dorsal root afferents depolarization in the neonatal rat spinal cord. Journal of Neurophysiology, 79, 2581-2592.

Levy, R. A. (1975). The effect of intravenously administered gamma-aminobutyric acid on afferent fiber polarization. Brain Research, 92, 21-34.

Marchetti, C., Tabak, J., Chub, N., O'Donovan, M. J., \& Rinzel, J. (2005). Modeling spontaneous activity in the developing spinal cord using activity-dependent variations of intracellular chloride. Journal of Neuroscience, 25, 3601-3612.

Mazzocchio, R., \& Rossi, A. (1997). Involvement of spinal recurrent inhibition in spasticity. Further insight into the regulation of Renshaw cell activity. Brain, $120(\mathrm{Pt} 6)$, 991-1003.

Morita, H., Crone, C., Christenhuis, D., Petersen, N. T., \& Nielsen, J. B. (2001). Modulation of presynaptic inhibition and disynaptic reciprocal Ia inhibition during voluntary movement in spasticity. Brain, 124, 826-837.

Myers, C. P., Lewcock, J. W., Hanson, M. G., Gosgnach, S., Aimone, J. B., Gage, F. H., et al. (2005). Cholinergic input is required during embryonic development to mediate proper assembly of spinal locomotor circuits. Neuron, 46, 37-49.

Nishimaru, H., Iizuka, M., Ozaki, S., \& Kudo, N. (1996). Spontaneous motoneuronal activity mediated by glycine and GABA in the spinal cord of rat fetuses in vitro. Journal of Physiology, 497, 131-143.

Nishimaru, H., \& Kudo, N. (2000). Formation of the central pattern generator for locomotion in the rat and mouse. Brain Research Bulletin, 53, 661-669.

Norreel, J.-C., Pflieger, J.-F., Pearlstein, E., Simeoni-Alias, J., Clarac, F., \& Vinay, L. (2003). Reversible disorganization of the locomotor pattern after neonatal spinal cord transection in the rat. Journal of Neuroscience, 23, 1924-1932.

Payne, J. A., Rivera, C., Voipio, J., \& Kaila, K. (2003). Cation-chloride co-transporters in neuronal communication, development and trauma. Trends in Neurosciences, 26, 199-206.
Pilyavskii, A. I., Yakhnitsa, V. A., \& Bulgakova, N. V. (1988). Antidromic dorsal root impulses during naturally occurring locomotion in rats. Neurophysiology, 20, 417-422.

Plotkin, M. D., Snyder, E. Y., Hebert, S. C., \& Delpire, E. (1997). Expression of the $\mathrm{Na}-\mathrm{K}-2 \mathrm{Cl}$ cotransporter is developmentally regulated in postnatal rat brains: A possible mechanism underlying GABA's excitatory role in immature brain. Journal of Neurobiology, 33, 781-795.

Ramirez, J. M., Telgkamp, P., Elsen, F. P., Quellmalz, U. J., \& Richter, D. W. (1997). Respiratory rhythm generation in mammals: Synaptic and membrane properties. Respiratory Physiology, 110, 71-85.

Ren, J., \& Greer, J. J. (2003). Ontogeny of rhythmic motor patterns generated in the embryonic rat spinal cord. Journal of Neurophysiology, 89, 1187-1195.

Ren, J., \& Greer, J. J. (2006). Modulation of respiratory rhythmogenesis by chloride-mediated conductances during the perinatal period. Journal of Neuroscience, 26, 3721-3730.

Rivera, C., Voipio, J., \& Kaila, K. (2004). Two developmental switches in GABAergic signalling: The $\mathrm{K}-\mathrm{Cl}$ cotransporter KCC2, and carbonic anhydrase CAVII. Journal of Physiology, 562, 27-36.

Rivera, C., Voipio, J., Payne, J. A., Ruusuvuori, E., Lahtinen, H., Lamsa, K., et al. (1999). The $\mathrm{K}^{+} / \mathrm{Cl}^{-}$co-transporter KCC2 renders GABA hyperpolarizing during neuronal maturation. Nature, 397, 251-255.

Rossignol, S., Beloozerova, I. N., Gossard, J. P., \& Dubuc, R. (1998). Presynaptic mechanisms during locomotion. In P. Rudomin, R. Romo \& L. M. Mendell (Eds.), Presynaptic inhibition and neural control (pp. 385-397). Oxford: Oxford University Press.

Rudomin, P. (1990). Presynaptic inhibition of muscle spindle and tendon organ afferents in the mammalian spinal cord. Trends in Neurosciences, 13, 499-505.

Rudomin, P., Engberg, I., \& Jimenez, I. (1981). Mechanisms involved in presynaptic depolarization of group I and rubrospinal fibers in cat spinal cord. Journal of Neurophysiology, 46, 532-548.

Rudomin, P., Quevedo, J., \& Eguibar, J. R. (1993). Presynaptic modulation of spinal reflexes. Current Opinion in Neurobiology, 3, 997-1004.

Sadlaoud, K., Tazerart, S., Brocard, C., Jean-Xavier, C., Portalier, P., Brocard, F., et al. (2010). Differential plasticity of the GABAergic and glycinergic synaptic transmission to rat lumbar motoneurons after spinal cord injury. Journal of Neuroscience, 30, 3358-3369.

Shao, X. M., \& Feldman, J. L. (1997). Respiratory rhythm generation and synaptic inhibition of expiratory neurons in preBotzinger complex: Differential roles of glycinergic and GABAergic neural transmission. Journal of Neurophysiology, 77, 1853-1860. 
Stein, V., Hermans-Borgmeyer, I., Jentsch, T. J., \& Hubner, C. A. (2004). Expression of the $\mathrm{KCl}$ cotransporter KCC2 parallels neuronal maturation and the emergence of low intracellular chloride. Journal of Comparative Neurology, 468, 57-64.

Stil, A., Liabeuf, S., Jean-Xavier, C., Brocard, C., Viemari, J. C., \& Vinay, L. (2009). Developmental up-regulation of the potassium-chloride cotransporter type 2 in the rat lumbar spinal cord. Neuroscience, 164, 809-821.

Sun, D., \& Murali, S. G. (1999). $\mathrm{Na}^{+}-\mathrm{K}^{+}-2 \mathrm{Cl}^{-}$cotransporter in immature cortical neurons: A role in intracellular $\mathrm{Cl}^{-}$regulation. Journal of Neurophysiology, 81, 1939-1948.

Sung, K. W., Kirby, M., McDonald, M. P., Lovinger, D. M., \& Delpire, E. (2000). Abnormal GABA $\mathrm{A}$ receptor-mediated currents in dorsal root ganglion neurons isolated from $\mathrm{Na}-\mathrm{K}-2 \mathrm{Cl}$ cotransporter null mice. Journal of Neuroscience, 20, 7531-7538.

Takahashi, T. (1984). Inhibitory miniature synaptic potentials in rat motoneurons. Proceedings of Royal Society of London B Biological Sciences, 221, 103-109.

Toennies, J. F. (1938). Reflex discharge from the spinal cord over the dorsal roots. Journal of Neurophysiology, 1, 378-390.

Vardi, N., Zhang, L. L., Payne, J. A., \& Sterling, P. (2000). Evidence that different cation chloride cotransporters in retinal neurons allow opposite responses to GABA. Journal of Neuroscience, 20, 7657-7663.

Verdier, D., Lund, J. P., \& Kolta, A. (2003). GABAergic control of action potential propagation along axonal branches of mammalian sensory neurons. Journal of Neuroscience, 23, 2002-2007.

Vinay, L., Brocard, F., Clarac, F., Norreel, J. C., Pearlstein, E., \& Pflieger, J. F. (2002). Development of posture and locomotion: An interplay of endogenously generated activities and neurotrophic actions by descending pathways. Brain Research Review, 40, 118-129.

Vinay, L., Brocard, F., Fellippa-Marques, S., \& Clarac, F. (1999). Antidromic discharges of dorsal root afferents in the neonatal rat. Journal of Physiology Paris, 93, 359-367.

Vinay, L., Brocard, F., Pflieger, J. F., Simeoni-Alias, J., \& Clarac, F. (2000). Perinatal development of lumbar motoneurons and their inputs in the rat. Brain Research Bulletin, 53, 635-647.

Vinay, L., \& Clarac, F. (1999). Antidromic discharges of dorsal root afferents and inhibition of the lumbar monosynaptic reflex in the neonatal rat. Neuroscience, 90, 165-176.

Vinay, L., \& Jean-Xavier, C. (2008). Plasticity of spinal cord locomotor networks and contribution of cation-chloride cotransporters. Brain Research Review, 57, 103-110.

Wu, W.-L., Ziskind-Conhaim, L., \& Sweet, M. A. (1992). Early development of glycine- and GABA-mediated synapses in rat spinal cord. Journal of Neuroscience, 12, 3935-3945.

Ziskind-Conhaim, L. (1998). Physiological functions of GABA-induced depolarizations in the developing rat spinal cord. Perspectives on Developemental Neurobiology, 5, 279-287. 